\title{
THE GENETIC CONTROL OF DS-RNA VIRUS-LIKE PARTICLES ASSOCIATED WITH SACCHAROMYCES CEREVISIAE KILLER YEAST
}

\author{
DIANE J. MITCHELL, A. J. HERRING and E. A. BEVAN \\ Department of Plant Biology and Microbiology, Queen Mary College, \\ University of London, London E1 4 NS
}

Received 23.ii.76

\begin{abstract}
Summary
Previous results have indicated that laboratory strains of yeast possessing two types of dsRNA virus-like particles, V1 and V2, are capable of producing a killer toxin which kills sensitive strains. This paper reports on genetic crosses which correlate the presence of these particles both with a host nuclear gene $\pm / m a k_{1}{ }^{*}$ and with the production of a killer toxin. The results show that:

(i) Vl particles are inherited independently of the $\pm / m a k_{1}$ gene.

(ii) V2 particles are present only in combination with those of $\mathrm{Vl}$ and the \pm allele of the $\pm / m a k_{1}$ nuclear gene.
\end{abstract}

\section{INTRODUGTION}

KILLER strains of yeast release a toxin into the growth medium to which they are themselves immune but which can kill sensitive strains of yeast under appropriate conditions (Bevan and Makower, 1963; Woods and Bevan, 1968; Bussey, 1972). These killer strains possess two viruses containing different, high molecular weight species of dsRNA (Berry and Bevan, 1972; Bevan, Herring and Mitchell, 1973; Vodkin and Fink, 1973; Herring and Bevan, 1974). The higher molecular weight species of dsRNA (m. wt $2.5 \times$ $10^{6}$ ) has been designated Pl and the lower molecular weight species (m. wt $1.4 \times 10^{6}$ ) as P2 (Bevan, Herring and Mitchell, 1973). P1 and P2 dsRNA species have been shown to be components of separately encapsidated viruses (Herring and Bevan, 1974). The Pl dsRNA containing virus has been termed the V1 particle and P2 dsRNA containing virus the V2 particle.

The results of a strain survey and the analysis of 5-fluorouracil-induced sensitive mutants (Mitchell, Bevan and Herring, 1973) indicated that the killer strains possess both V1 and V2 particles, since both P1 and P2 dsRNA were present, whilst sensitive strains either possess $\mathrm{Vl}$ alone or neither particle.

These findings led naturally to a series of genetic crosses, reported in this paper, which were undertaken to elucidate the relationships between the two particles V1 and V2 and the nuclear maintenance gene $\pm / m a k_{1}(\equiv \mathrm{M} / \mathrm{m}$; Somers and Bevan, 1969). Killer and sensitive strains, previously characterised as to their V1 and V2 content, were crossed and the segregation patterns of the dsRNA species amongst the progeny were established. Since it had already been shown (Herring and Bevan, 1974) that the presence of the dsRNA species $\mathrm{P} 1$ and $\mathrm{P} 2$ is indicative of the presence of $\mathrm{V} 1$ and V2, the

* Known previously as $M / m$. 
characterisation of the progeny was based both on the analysis of their dsRNA content and the determination of their phenotypes with regard to the killer character.

\section{Materials and methods}

The haploid auxotrophic and prototrophic strains of Saccharomyces cerevisiae used were:

\begin{tabular}{|c|c|c|c|c|c|}
\hline \multicolumn{2}{|c|}{ Genotype } & \multicolumn{2}{|c|}{ VLP content } & Phenotype & Designation \\
\hline \pm & $\alpha \arg _{9}$ & V1 & $\mathrm{V} 2$ & Killer & $\mathrm{K} 10$ \\
\hline \pm & $a$ ade 2.8 & V1 & V2 & Killer & $\mathrm{K} 22.704$ \\
\hline \pm & $a \quad \arg _{9}$ & Vl & $\mathrm{V} 2$ & Killer & $\mathrm{K} 7$ \\
\hline \pm & $\alpha a d e_{2.5}$ & Vl & $\mathrm{V} 2$ & Killer & $\mathrm{K} 12$ \\
\hline \pm & a try $y_{5} l e u_{1}$ & V1 & $\mathrm{V} 2$ & Killer & JK19 \\
\hline & $a a^{a d e_{2.1}}$ & - & - & Sensitive & SX \\
\hline$m a k_{1}$ & $\alpha$ & - & - & Sensitive & S3 \\
\hline$m a k_{1}$ & $a \arg _{9}$ & - & - & Sensitive & $\mathrm{R} 9.4 \mathrm{C}$ \\
\hline \pm & $a$ ade 2.8 & V1 & - & Sensitive & SK22 \\
\hline$\overline{m a k} k_{1}$ & $a$ ade $e_{2.1}$ & Vl & - & Sensitive & S9 \\
\hline$m a k_{1}$ & $a$ & V1 & - & Sensitive & S5 \\
\hline \pm & $a \quad \arg _{9}$ & V1 & - & Sensitive & SSK7 \\
\hline$m a k_{1}$ & $\alpha a_{2.5}$ & V1 & - & Sensitive & SR18 \\
\hline \pm & $a$ his $_{\mathbf{4}}$ & V1 & - & Sensitive & JN5 \\
\hline$m a k_{1}$ & $\alpha \arg _{9}$ & Vl & - & Sensitive & SCol.3 \\
\hline$m a k_{1}$ & $\alpha$ ade $_{2.8}$ & V1 & - & Sensitive & R7.2B \\
\hline$m a k_{1}$ & $\alpha$ ade $_{2.8}$ & V1 & - & Sensitive & R7.6C \\
\hline$m a k_{1}$ & $a$ ade 2.8 & Vl & - & Sensitive & R7.6D \\
\hline
\end{tabular}

All the strains with the exception of one were stock cultures, or their derivatives, of this laboratory. The exception was K22.704 which originated from D. Wilkie's laboratory (University College, London).

The media used for mating and growth were: $(a)$ Wickerman's defined minimal medium and $(b)$ complete medium ( 1 per cent yeast extract, 1 per cent bacto peptone, 2 per cent glucose and 1.5 per cent agar. Acetate medium was used to induce sporulation (Pomper, Daniels and McKee, 1954).

Crosses involving the auxotrophic strains were carried out by complementation on minimal medium. Those involving the prototrophic strain S3 were undertaken on complete medium. Single diploid cells were isolated, grown into a colony and the cells sporulated.

Tetrad analyses were carried out after the asci walls had first been dissolved using either helicase* or mushroom enzyme (Bevan and Costello, 1964). The tetrads were separated using a Singer micromanipulator (Barer and Saunders-Singer, 1948), in conjunction with a Wild binocular microscope (M11-37919) magnifying $\times 225$ and with the open plate method of micromanipulation (Kemp and Bevan, 1959) adapted for yeast (Bevan and Woods, 1963). Microloops of $c .70 \mu$ diameter were made on a De Fonbrunne microforge (De Fonbrunne, 1949).

Details of the phenol extraction technique used for nucleic acid preparations, and the subsequent separation and characterisation of these nucleic

* Suc d'helix pomatia-Industrie Biologique Française. 
acids by polyacrylamide gel electrophoresis, are given elsewhere in Bevan, Herring and Mitchell (1973).

\section{RESUlts}

(i) Killer $\times$ Sensitive and Sensitive $\times$ Sensitive crosses

All crosses shown in table 1 gave a normal segregation of the killer phenotype with the $\pm / m a k_{1}$ gene, i.e. in a $\pm(\mathrm{K}) \dagger \times m a k_{1}$ (S) $\dagger$ cross the progeny segregated $2 \mathrm{~K}: 2 \mathrm{~S}$ and in $\mathrm{a} \pm(\mathrm{K}) \times \pm(\mathrm{S})$ the progeny segregated $4 \mathrm{~K}: 0 \mathrm{~S}$.

\section{TABLE 1}

Killer $\times$ Sensitive crosses undertaken to establish a correlation between the Killer/Sensitive phenotype and $V L P$ content

\begin{tabular}{|c|c|c|c|c|c|}
\hline \multirow[b]{2}{*}{$\begin{array}{l}\text { Cross } \\
\text { No. }\end{array}$} & \multicolumn{3}{|c|}{ Strains crossed } & \multirow{2}{*}{$\begin{array}{c}\text { No. of } \\
\text { tetrads } \\
\text { analysed }\end{array}$} & \multirow{2}{*}{$\begin{array}{c}\text { Killer/Sensitive } \\
\text { phenotype and VLP } \\
\text { content }\end{array}$} \\
\hline & Designation & $\begin{array}{c}\text { Genotypes and } \\
\text { phenotypes }\end{array}$ & & & \\
\hline R21 & $\mathrm{K} 10 \times \mathrm{SK} 22$ & $\pm V 1 V 2(\mathrm{~K}) \times \pm$ & $\mathrm{VI}-(\mathrm{S})$ & 10 & $4 \mathrm{~V} 1 \mathrm{~V} 2(\mathrm{~K}): 0(\mathrm{~S})$ \\
\hline $\mathrm{R} 1$ & $\mathrm{~K} 10 \times \mathrm{SX}$ & $\pm \mathrm{V} 1 \mathrm{~V} 2(\mathrm{~K}) \times \pm$ & $--(S)$ & 7 & $4 \mathrm{~V} 1 \mathrm{~V} 2(\mathrm{~K}): 0(\mathrm{~S})$ \\
\hline $\mathrm{R} 2$ & $\mathrm{~K} 10 \times \mathrm{S} 9$ & $\pm \mathrm{V} 1 \mathrm{~V} 2(\mathrm{~K}) \times m a k_{1}$ & $\mathrm{VI}-(\mathrm{S})$ & 14 & $2 \mathrm{~V} 1 \mathrm{~V} 2(\mathrm{~K}): 2 \mathrm{V1}-(\mathrm{S})$ \\
\hline R3 & $\mathrm{K} 10 \times \mathrm{R} 7.6 \mathrm{D}$ & $\pm \mathrm{V} 1 \mathrm{~V} 2(\mathrm{~K}) \times m a k_{1}$ & $\mathrm{~V} 1-(\mathrm{S})$ & 5 & $2 \mathrm{~V} 1 \mathrm{~V} 2(\mathrm{~K}): 2 \mathrm{Vl}-(\mathrm{S})$ \\
\hline R8 & $\mathrm{K} 10 \times \mathrm{S} 5$ & $\pm \mathrm{V} 1 \mathrm{~V} 2(\mathrm{~K}) \times m a k_{1}$ & $\mathrm{~V} 1-(\mathrm{S})$ & 5 & $2 \mathrm{~V} 1 \mathrm{~V} 2(\mathrm{~K}): 2 \mathrm{~V} 1-(\mathrm{S})$ \\
\hline
\end{tabular}

VLP: Virus-like particle.

$\pm / m a k_{1}$ : Nuclear maintenance gene.

$\mathrm{V} 1$ and V2: VLPs containing $\mathrm{P} 1$ and P2 dsRNA species respectively.

$\mathrm{K}$ and $\mathrm{S}$ : Killer and Sensitive phenotypes respectively.

Similarly the progeny from the Sensitive $\times$ Sensitive crosses, table 2, segregated normally $0 \mathrm{~K}: 4 \mathrm{~S}$.

\section{TABLE 2}

Sensitive $\times$ Sensitive crosses undertaken to establish a correlation between the Killer/Sensitive phenotype and VLP content

\begin{tabular}{|c|c|c|c|c|}
\hline \multirow[b]{2}{*}{$\begin{array}{c}\text { Cross } \\
\text { no. }\end{array}$} & \multicolumn{2}{|r|}{ Strains crossed } & \multirow{2}{*}{$\begin{array}{l}\text { No. of } \\
\text { tetrads } \\
\text { analysed }\end{array}$} & \multirow{2}{*}{$\begin{array}{c}\text { Killer/Sensitive } \\
\text { phenotype and VLF } \\
\text { content }\end{array}$} \\
\hline & Designation & $\begin{array}{l}\text { Genotypes and } \\
\text { phenotypes }\end{array}$ & & \\
\hline 218 & $\operatorname{SSK} 7 \times \operatorname{SR} 18$ & $\pm \mathrm{V} 1-(\mathrm{S}) \times m a k_{1} \mathrm{Vl}-(\mathrm{S})$ & 4 & $0(\mathrm{~K}): 4 \mathrm{Vl}-(\mathrm{S})$ \\
\hline 27 & N5 $\times 5$ & $1-(\mathrm{S}) \times m a k_{1}-$ & 4 & $0(\mathrm{~K}): 4 \mathrm{Vl}-(\mathrm{S})$ \\
\hline & SX $\times$ SCol. 3 & $\pm--(\mathrm{S}) \times m a k_{1} \mathrm{~V} 1-(\mathrm{S})$ & 3 & $0(\mathrm{~K}): 4 \mathrm{Vl}-(\mathrm{S})$ \\
\hline 26 & $\times \mathrm{S} 3$ & $m a \overline{k_{1}} \mathrm{Vl}-(\mathrm{S}) \times m a k_{1}--(\mathrm{S})$ & 5 & $0(\mathrm{~K}): 4 \mathrm{Vl}-(\mathrm{S})$ \\
\hline
\end{tabular}

VLP: Virus-like particle.

$\pm / m a k_{1}$ : Nuclear maintenance gene.

$\mathrm{V} 1$ and V2: VLPs containing P1 and P2 dsRNA species, respectively.

$\mathrm{K}$ and $\mathrm{S}$ : Killer and Sensitive phenotypes, respectively.

The Vl particle was present in all the progeny listed in tables 1 and 2, whether of \pm or mak $k_{1}$ genotype. Thus, it is concluded that Vl is inherited cytoplasmically and independently of $\pm / m a k_{1}$. The V2 particle was found only in combination with V1 and in the presence of the \pm allele, i.e. V2 was

$\dagger$ See key to table 1 . 
present in all the \pm progeny if one of the parents was a \pm Vl V2 killer, but was found to be absent in all the mak progeny.

\section{(ii) The action of the $\mathrm{mak}_{1}$ allele}

The tetrad progeny of the Killer $\times$ Sensitive cross R7, segregated $2 \pm$ Vl V2:2 mak $\mathrm{VI}$ - (table 3$)$.

TABLE 3

Further crosses undertaken to establish a correlation between the Killer/Sensitive phenotype and VLP content

\begin{tabular}{|c|c|c|c|c|}
\hline \multirow[b]{2}{*}{$\begin{array}{c}\text { Cross } \\
\text { no. }\end{array}$} & \multicolumn{2}{|c|}{ Strains crossed } & \multirow{2}{*}{$\begin{array}{l}\text { No. of } \\
\text { tetrads } \\
\text { analysed }\end{array}$} & \multirow{2}{*}{$\begin{array}{c}\text { Killer/Sensitive } \\
\text { phenotype and VLP } \\
\text { content }\end{array}$} \\
\hline & Designation & $\begin{array}{l}\text { Genotypes and } \\
\text { phenotypes }\end{array}$ & & \\
\hline R7 & $\mathrm{K} 22.704 \times \mathrm{S} 3$ & $\pm \mathrm{V} 1 \mathrm{~V} 2(\mathrm{~K}) \times m a k_{1}--(\mathrm{S})$ & 7 & $2 \mathrm{~V} 1 \mathrm{~V} 2(\mathrm{~K}): 2 \mathrm{~V} 1-(\mathrm{S})$ \\
\hline R12 & $\mathrm{SX} \times \mathrm{R} 7.6 \mathrm{C}$ & \pm- - S $\times m a k_{1} \mathrm{~V} 1-(\mathrm{S})$ & 3 & $0(\mathrm{~K}) \quad: 4 \mathrm{~V} 1-(\mathrm{S})$ \\
\hline $\mathrm{R} 17$ & $\times \mathrm{R} 9.4 \mathrm{C}$ & $\pm \mathrm{V} 1 \mathrm{~V} 2(\mathrm{~K}) \times m a k_{1}--(\mathrm{S})$ & 3 & $2 \mathrm{~V} 1 \mathrm{~V} 2(\mathrm{~K}): 2 \mathrm{~V} 1-(\mathrm{S})$ \\
\hline R20 & JK19 & $\pm \mathrm{V} 1 \mathrm{~V} 2(\mathrm{~K}) \times \mathrm{mak}_{1}--(\mathrm{S})$ & 2 & $2 \mathrm{~V} 1 \mathrm{~V} 2(\mathrm{~K}): 2 \mathrm{~V} 1-(\mathrm{S})$ \\
\hline R10 & $\mathrm{K} 7 \times \mathrm{R} 7.2 \mathrm{~B}$ & $\pm \mathrm{V} 1 \mathrm{~V} 2(\mathbf{K}) \times m a k_{1} \mathrm{~V} 1-(\mathrm{S})$ & 4 & $2 \mathrm{~V} 1 \mathrm{~V} 2(\mathrm{~K}): 2 \mathrm{~V} 1-(\mathrm{S})$ \\
\hline R11 & $\mathrm{R} 10.5 \mathrm{~A} \times \mathrm{S} 3$ & $\pm \mathrm{V} 1 \mathrm{~V} 2(\mathrm{~K}) \times m a k_{1}--(\mathrm{S})$ & 4 & $2 \mathrm{~V} 1 \mathrm{~V} 2(\mathrm{~K}): 2 \mathrm{~V} 1-(\mathrm{S})$ \\
\hline
\end{tabular}

VLP: Virus-like particle.

$\pm / m a k_{1}$ : Nuclear maintenance gene.

$\mathrm{V} 1$ and V2: VLPs containing PI and P2 dsRNA species, respectively.

$\mathrm{K}$ and $\mathrm{S}$ : Killer and Sensitive phenotypes, respectively.

A possible explanation for this segregation is that the expression (i.e. the detectable presence) of V2 is suppressed by the mak 1 allele. This hypothesis was tested by analysing the results of the cross $\mathrm{R} 12$, between \pm-- and $m a k_{1} \mathrm{Vl}$ - (table 3), the latter strain having arisen from R7. If $m a k_{1}$ suppressed the expression of $\mathrm{V} 2$ in $m a k_{1} \mathrm{~V} 1-$, then one would have expected to recover $\pm \mathrm{Vl}$ V2 killers from $\pm--\times m a k_{1} \mathrm{Vl}-(\mathrm{R} 12)$. It will be seen from table 3 , however, that all the progeny were in fact $\mathrm{Vl}$ - sensitives. This means that the $m a k_{1}$ allele does not act by suppressing V2 but that V2 is not perpetuated in the presence of $m a k_{1}$.

\section{(iii) The segregational pattern of an exceptional killer strain}

The results of the Killer $\times$ Sensitive cross R9, between K7 ( \pm V1 V2 $(K)$ ) and S3 $\left(m a k_{1}--(\mathrm{S})\right)$ were at variance with those arising from all other crosses of the class $\pm \mathrm{V} 1 \mathrm{~V} 2(\mathrm{~K}) \times m a k_{1}--(\mathrm{S})$. Nine tetrads from R9 were examined and ratios of $2 \pm \mathrm{Vl} \mathrm{V} 2(\mathrm{~K}): 2 m^{2} k_{1}--(\mathrm{S})$, whereas R7, R17 and R20 (table 3) gave $2 \pm \mathrm{V} 1 \mathrm{~V} 2(\mathrm{~K}): 2 m_{1} k_{1} \mathrm{Vl}-(\mathrm{S})$ segregations. Four other crosses between different killer strains and ak $_{1}--(\mathbf{S})$ strains have since been carried out and initial results show that their segregations are the same as those for R7, R17 and R20.

The sensitive parent, S3, in all all four crosses, R9, R7, R17 and R20, was the same. Therefore the difference in segregational patterns was presumably due to the killer parents; this difference could either be a difference in the host genotype or a cytoplasmic difference. To test the hypothesis that the difference was due to a nuclear gene difference, the exceptional killer strain, K7, was crossed to a "normal" killer strain $\mathrm{K} 22.704$ and each of the four spores in one resultant tetrad was crossed to a 
$m a k_{1}--$ sensitive strain and the progeny analysed. A total of 28 tetrads from the four crosses were analysed, with the result that all the sensitive progeny were demonstrated as being $m a k_{1} \mathrm{Vl}-$. This is inconsistent with a nuclear gene difference between $\mathrm{K} 7$ and $\mathrm{K} 22.704$ being responsible for the difference in their behaviour when each is crossed to $m a k_{1}--(S)$ but is consistent with a cystoplasmic difference. Further crosses are underway in an attempt to elucidate the nature of this cytoplasmic difference.

\section{Discussion}

The results of investigations described here confirm that $\mathrm{V} 1$ particles are inherited cytoplasmically and that their maintenance is independent of the action of the nuclear gene $\pm / m a k_{1}$. On the other hand, the V2 cytoplasmic particles are dependent on both the presence of $\mathrm{Vl}$ particles and the \pm allele of this gene. These results confirm those of Herring and Bevan (1974), whose biochemical studies indicate that V1 and V2 particles are genetically distinct in that they are associated with different dsRNA species.

The release of the killer toxin by cells is dependent on the presence of V2 particles. Those lacking V2 particles are always sensitive to the toxin irrespective of the presence of V1 particles or the action of the $\pm / m a k_{1}$ gene.

Crosses between Killers and Sensitives where K7 was the parent killer yielded segregations not consistent with those of other such crosses. The abnormal results obtained support the hypothesis that $\mathrm{K} 7$ differs cytoplasmically from the other killer strains. Whether or not such a cytoplasmic difference can be equated with mutant V1 or V2 particles remains to be elucidated by futher investigations.

Acknowledgments. - The authors wish to thank Miss Rosemarie Smith, and especially Mr Michael Relf for expert technical assistance. This work was supported, in part, by a grant to Professor E. A. Bevan from the Science Research Council.

\section{References}

BARER, R., AND SAUNDERS-SINGER, A. E. 1948. A new single-control micro-manipulator. Quart. 7. Micro. Sci., 89, 437-439.

BERRY, E. A., AND BEVAN, E. A. 1972. A new species of double-stranded RNA from yeast. Nature, 239, 279-280.

BEVAN, E. A., AND COSTELlo, w. P. 1964. The preparation and use of an enzyme which breaks open yeast asci. Microb. Gen. Bull., $21,5$.

BeVAN, E. A., HeRring, A. J., AND Mitchell, D. J. 1973. Preliminary characterisation of two species of dsRNA in yeast and their relationship to the " killer" character. Nature, 246, 81-85.

BEVAN, E. A., AND MAKOWER, M. 1963. The physiological basis of the killer character in yeast. In Proc. XIth Int. Congr. Genetics, Volume I. Pergamon Press, The Netherlands.

BEVAN, E. A., AND woods, R. A. 1963. The use of yeast for teaching practical genetics. In Teaching Genetics in School and University, ed. C. D. Darlington and A. D. Bradshaw, pp. 29-35. Oliver \& Boyd, London.

BUSSEY, H. 1972. Effects of yeast killer factor on sensitive cells. Nature, New Biol., 235, 73-75.

DE Fonbrunne, P. 1949. Technique de micromanipulation. Masson, Paris.

HERRING, A. J., AND BEVAN, E. A. 1974. Virus-like particles associated with the doublestranded RNA species found in killer and sensitive strains of the yeast Saccharomyces cerevisiae. 7. gen. Virol., 22, 387-394.

KEMP, R. F. O., AND BEVAN, E. A. 1959. New techniques for isolating spores of Hymenomycetes. Trans. Brit. Mycol. Soc., 42, 308-311. 
MTTChell, D. J., BEVAN, E. A., AND heRRING, A. J. 1973. The correlation between dsRNA in yeast and the "killer character". Heredity, 31, 133-134.

POMPER, s., DANIELS, X. M., AND MCKEE, D. w. 1954. Genetic analysis of polyploid yeast. Genetics, 39, 343-355.

SOMERS, J. M., AND BEVAN, E. A. 1969. The inheritance of the killer character in yeast. Genet. Res. Camb., 13, 71-83.

voDKIN, M. H., AND FINK, G. R. 1973. A nucleic acid associated with a killer strain of yeast. Proc. Nat. Acad. Sci., U.S.A., 70, No. 4, 1069-1076.

WOODS, D. R., AND BEVAN, E. A. 1968. Studies on the nature of the killer factor produced by Saccharomyces cerevisiae. 7. Gen. Microbiol., 51, 115-126. 